\title{
SZARA STREFA A REDYSTRYBUCJA PKB - IMPLIKACJE, UWARUNKOWANIA
}

\section{Wprowadzenie}

Rozważając dystrybucję PKB przez sektor publiczny, należy uwzględnić model gospodarki i uwarunkowania spowodowane nie tylko sprawnością instytucjonalną, ale również ogólną sytuacją makroekonomiczną danego państwa. Ponadto redystrybucja jest rozpatrywana nie tylko od strony wydatków, ale także potrzeb fiskalnych państwa. W literaturze przedmiotu występują zazwyczaj dwa odmienne podejścia. System fiskalny jest determinowany przez potrzeby wydatkowe lub też wydatki są zmienną niezależną od wysokości podatków ${ }^{1}$. Poprzez skalę redystrybucji można ustalić potrzeby w zakresie tempa wzrostu gospodarczego, kierunków rozdysponowania środków publicznych, roszczeń obywateli, konsekwencji w polityce gospodarczej. Sektor finansów publicznych (zwłaszcza w gospodarce rynkowej) odgrywa niezmiernie ważną rolę zarówno w sferze stabilizacji makroekonomicznej, jak i w sferze pobudzania koniunktury gospodarczej². Wykorzystuje się w tym zakresie dwie funkcje: aktywną oraz pasywną. Funkcja aktywna polega na zastosowaniu odpowiedniej skali opodatkowania i wydatków publicznych do pobudzenia (ale także niekiedy „schłodzenia”) koniunktury. Wyróżnia się politykę ekspansywną oraz restrykcyjną ${ }^{3}$. Natomiast funkcja pasywna opiera się na zastosowaniu tzw. stabilizatorów, które działają niezależnie od sytuacji makroekonomicznej. Znając poziom dystrybucji, można uzyskać nie tylko informację o skali zjawiska, ale także dane co do kierunków polityki inwestycyjnej, konsumpcyjnej państwa oraz uwarunkowań ekonomiczno-społecznych.

1 L. Balcerowicz, Ekonomia i etyka państwa socjalnego, Wykład dla Polskiej Rady Biznesu, Warszawa, 1.02.2006.

2 E. Małecka-Ziembińska, Finanse publiczne państw OECD w dobie kryzysu, „Zeszyty Naukowe PTE” nr 10, 2011.

3 R. Barczyk, M. Lubiński, Dylematy stabilizowania koniunktury, Wydawnictwo UE w Poznaniu, Poznań 2009. 
Rysunek 1. Wydatki sektora instytucji rządowych i samorządowych jako \% PKB (ujęcie nominalne) w wybranych państwach Unii Europejskiej w latach 2002-2013

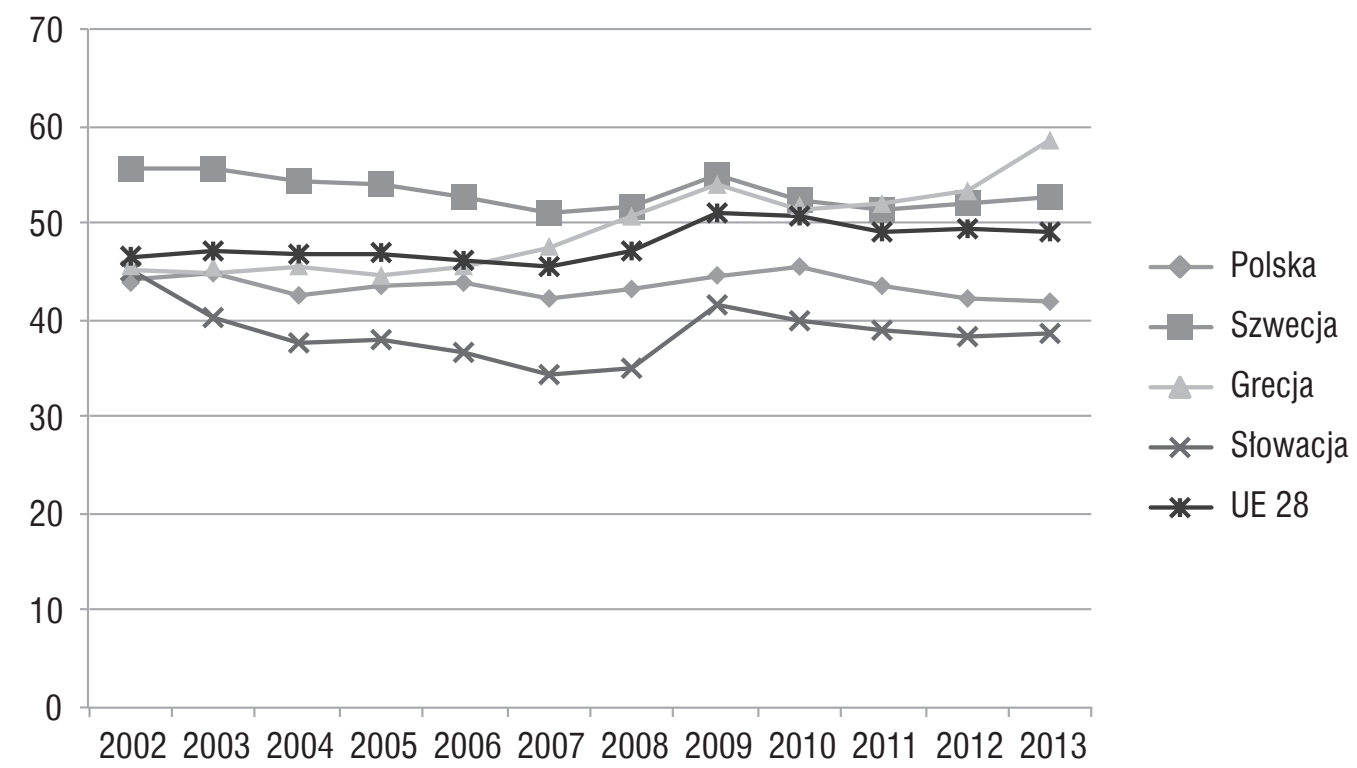

Źródło: Eurostat [dostęp 12.01.2015].

Analizując dane przedstawione na rysunku 1, należy odnotować, iż w Polsce nastąpił spadek udziału wydatków publicznych o $2,4 \%$. Natomiast w państwach UE miał miejsce wzrost o 2,5\% i w 2013 r. wydatki te osiągnęły poziom 49,1\% PKB. Jednak w niektórych krajach Europy wydatki publiczne były zdecydowanie wyższe. Takim przykładem są państwa skandynawskie (a szerzej ujmując nordyckie), gdzie poziom ten (np. w Szwecji) przekracza 50\%, w Finlandii udział ten w 2013 r. osiągnął pułap 58\% PKB. Można przyjąć, że tak wysoki poziom z jednej strony uwarunkowany jest modelem gospodarczym (relatywnie duże wydatki socjalne), a z drugiej wysokim fiskalizmem. W innych krajach wysoki poziom wydatków publicznych (np. w Grecji w 2002 r. było to $45,1 \%$, a w 2013 r. już 58,5\% PKB) wynikał z błędnej polityki makroekonomicznej, zbyt rozbudowanych świadczeń socjalnych, wydatków rządowych niemających ekonomicznego uzasadnienia. W konsekwencji taka polityka doprowadziła do ostrego kryzysu gospodarczego.

Na podstawie analizy wydatków publicznych w państwach UE należy stwierdzić, że: - wzrasta rola państwa w procesach regulacyjnych; dotyczy to zarówno sytuacji, w której wydatki się zwiększają, jak i takiej, w której wydatki ulegają wyraźnemu obniżeniu, np. w Słowacji;

- zmienia się możliwość redystrybucji z uwagi na zmniejszenie się tempa wzrostu $\mathrm{PKB}$, a nawet recesji.

Rozpatrując uwarunkowania redystrybucji, należy także uwzględnić funkcjonowanie szarej strefy. Szara strefa występuje w każdej gospodarce, różni się jedynie skalą 
i formą działania. Szara strefa implikuje działania gospodarstw domowych, przedsiębiorstw, sprawność instytucjonalną państwa, a co się z tym wiąże, także podejmowanie decyzji odnośnie do stopnia redystrybucji ${ }^{4}$. Szara strefa wynika także z ogólnej sytuacji ekonomicznej państwa. Tam, gdzie państwo jest słabe, nie radzi sobie z rozwiązywaniem problemów społeczno-ekonomicznych, pojawia się szara strefa ${ }^{5}$.

\section{Cel artykułu, przyjęte metody badawcze i hipotezy}

W artykule przyjęto dwa cele: główny i poboczny. Celem głównym jest ustalenie związku pomiędzy wielkością szarej strefy a poziomem redystrybucji PKB. Posłużono się współczynnikiem korelacji Pearsona dla małych prób. Przyjęto poziom istotności 0,05 dla dwustronnego testowania, przy liczbie stopni swobody $\mathrm{df}=18$. Punkt graniczny wyznaczono na poziomie 0,444 . Wykorzystano rozkład t-Studenta. Do ustalenia zależności korelacyjnej pomiędzy przyjętymi zmiennymi wykorzystano podejście J. Guilforda, w którym ustalono siłę związku:

$\mathrm{r} \mid=0$ - brak korelacji,

$0,0<|\mathrm{r}| \leq 0,1-$ korelacja nikła,

$0,1<|\mathrm{r}| \leq 0,3$ - korelacja słaba,

$0,3<|\mathrm{r}| \leq 0,5$ - korelacja przeciętna,

$0,5<|\mathrm{r}| \leq 0,7$ - korelacja wysoka,

$0,7<|\mathrm{r}| \leq 0,9$ - korelacja bardzo wysoka,

$0,9<|\mathrm{r}|<1,0$ - korelacja niemal pełna,

$|\mathrm{r}|=1$ - korelacja pełna.

Do obliczeń posłużono się programem Microsoft Excel 2010, a wartości krytyczne odczytano z tablicy rozkładu r-Pearsona.

Analizie poddano następujące kraje: Polskę, Czechy, Słowację, Bułgarię oraz Węgry. Wybór krajów był celowy. Do 1990 r. kraje te posiadały zbliżony model gospodarczy. Następnie przyjęły plan reform, przechodzenia od gospodarki planowej do rynkowej, ukierunkowany na ścisłą współpracę w ramach Unii Europejskiej. Należy podkreślić, że zakres reform, tempo zmian w poszczególnych krajach znacznie się od siebie różniły. $Z$ tego względu współczynnik korelacji liczono odrębnie dla każdego z przyjętych do analizy państw. Podejście to jest odmienne od tego, które

4 S. Johnson, D. Kaufniann, P. Zoido-Lobaton, Regulatory Discretion and the Unofficial Economy, „Economic Review" Nr 88(2), 1998.

5 A. Buszko, Finanse przestępczości zorganizowanej, TNOiK, Toruń 2014. 
zastosowali Yair Eilat i Clifford Zinnes, badając poziom szarej strefy, grupowali oni państwa w ujęciu regionalnym. Zdaniem autora powoduje to zacieranie się różnic, znacznych odrębności pomiędzy poszczególnymi krajami, a osiągnięty w ten sposób wynik jest zbyt ogólny, aby można było wyciągnąć uniwersalne wnioski ${ }^{6}$. Analizą objęto lata 1994-2014.

Celem pobocznym jest próba przedstawienia roli szarej strefy w procesach gospodarczych implikujących poziom wydatków publicznych.

Przyjęto hipotezę o następującej treści: Poziom wydatków publicznych jest silnie stochastycznie dodatnio skorelowany z poziomem szarej strefy. Zastosowano indukcję oraz redukcję jako metody wnioskowania naukowego.

\section{Przesłanki powstania i rodzaje szarej strefy}

Powstanie i rozwój szarej strefy są podyktowane szeregiem istotnych czynników. Wielu autorów podkreśla związek obciążeń podatkowych z szarą strefą. Zbyt duże obciążenia skutkują powstaniem szarej strefy ${ }^{7}$. Oprócz wysokości zobowiązań podatkowych istotnym uwarunkowaniem (klasyczny przypadek Polski) jest nadmiernie złożony system prawny. Przepisy są zbyt skomplikowane, często ze sobą sprzeczne i niezrozumiałe nie tylko dla podatników, ale także dla urzędników państwowych. W takim przypadku można przyjąć założenie, że zdecydowana większość podmiotów znajduje się w szarej strefie z uwagi na brak możliwości stosowania się do obowiązującego systemu prawnego. Słabość państwa warunkuje powstanie szarej strefy. Państwo nie jest w stanie rozwiązać problemów społeczno-gospodarczych i tę przestrzeń wypełnia szara strefa. Przykładem takiej sytuacji jest przypadek tzw. gospodarki niedoboru. Brak wielu produktów na rynku skutkował nielegalną produkcją, przemytem. Nadmierna regulacja prowadzenia działalności gospodarczej, przejawiająca się np. dużą liczbą otrzymania niezbędnych koncesji, pozwoleń przyczynia się także do powstania szarej strefy. Korupcja, w tym korupcja urzędników państwowych, którzy w praktyce wymuszają wręczanie łapówek, jest w wielu krajach (np. Rosja, Ukraina, państwa arabskie) ważnym impulsem powstania szarej strefy.

6 Y. Eilat, C. Zinnes, The Shadow Economy in Transition Countries: Friend or Foe?, „A Policy Perspective. World Development" Vol. 30, Nr 7, 2002.

7 B. Mróz, The shadow economy in Poland. Causes, Manifestations, Economic and Social Effects, „Journal of Management and Financial Sciences" Vol. III, Issue 3, April 2010 oraz M. Pasternak-Malicka, Model Laffera jako wdrożenie mainstreamowego pogladu na zależność pomiędzy wysokościa podatku a ekspansja szarej strefy, w: Rozwój nauki o finansach. Stan obecny i pożądane kierunki jej ewolucji, red. nauk. J. Ostaszewski, E. Kosycarz, S. „Przedsiębiorczość”, Oficyna Wydawnicza SGH, Warszawa 2014. 
Przestępczość zorganizowana nie tylko jest działaniem niezgodnym z obowiązującym prawem, ale także przyczynia się do zwiększenia zakresu szarej strefy. Przedsiębiorcy ( $\mathrm{z}$ uwagi na chęć unikania kontaktów z przestępczością zorganizowaną) często działają w taki sposób, aby ich funkcjonowanie nie było zauważone zarówno przez władze, jak i przez przestępców. Można w tym zakresie przytoczyć przypadek Słowenii. Kraj relatywnie (na tle pozostałych państw powstałych po rozpadzie Jugosławii) dobrze rozwinięty gospodarczo, ale z wysokim poziomem szarej strefy - blisko $30 \% \mathrm{PKB}^{8}$.

W ujęciu historycznym (po zniesieniu feudalizmu w 1848 r.) Słoweńcy musieli nabyć relatywnie niewielkie farmy. Zaciągali kredyty w powstających bankach, a z drugiej strony monarchia austro-węgierska obciążyła Słoweńców wysokimi podatkami, podyktowanymi wydatkami na dozbrojenie wojska. Władza była postrzegana jako „obca siła” nadmiernie wyzyskująca miejscowych. Równolegle wśród Słoweńców wykształciła się forma współpracy sąsiedzkiej. Trudno było utrzymać się na niewielkich farmach (nawet do tej pory struktura agrarna w Słowenii charakteryzuje się dużym udziałem małych gospodarstw rolnych - zwłaszcza na tle innych państw Unii Europejskiej) i następowała wymiana dobór oraz usług, z całkowitym pominięciem oficjalnego obiegu. W obrębie niewielkich nieoficjalnych zrzeszeń produkowano nie tylko żywność, ubrania, meble, sprzęt gospodarczy, ale i wyroby wysokiej jakości, np. metalowe (kowalstwo artystyczne - rejon Dolenjska). Za te produkty uzyskiwano nawet wysoką cenę. Ten obrót należy zakwalifikować do typowej szarej strefy, w klasie działalność nierejestrowana. Praktycznie do czasów I wojny światowej cały przemysł był w rękach Niemców i Austriaków. Słoweńcy koncentrowali się na rozwoju rzemiosła i produkcji rolnej, wytwory tej działalności były rozprowadzane z pominięciem oficjalnej dystrybucji. W ten sposób utrwaliła się akceptacja wszelkich form działania w szarej strefie.

Po II wojnie światowej zrzeszenia producentów, swoiste spółdzielnie produkcyjno-usługowe (dawnej Jugosławii) otrzymały wsparcie rządowe - jako forma własności społecznej. Jednak nadal występowała typowa działalność w szarej strefie. Menedżerowie (zwłaszcza kierownicy średniego szczebla) koncentrowali się nie tylko na wypełnianiu planów, ale na takim gospodarowaniu majątkiem, aby nadwyżki można było (tak jak w znacznym stopniu było w Słowenii) wprowadzić do obrotu w szarej strefy. Zarobione w ten sposób środki były inwestowane w nieruchomości oraz rozwijanie własnego prywatnego biznesu. Bardzo często następowała współpraca pomiędzy państwowymi spółdzielniami a prywatnymi podmiotami, gdzie

8 A. Buszko, J. Długosz, J. Skorwider-Namiotko, K. Szumowska, Zarządzanie przedsiębiorstwem szarej strefy, Difin, Warszawa 2015 [w druku]. 
funkcje zarządcze pełniły te same osoby. Powstawał swoisty konglomerat zależności, w którym trudno było (z ekonomicznego punktu widzenia) wyodrębnić podmioty, a znaczna część operacji odbywała się w szarej strefie. Dodatkowo menedżerowie posiadali rozbudowane kontakty gospodarcze z Europą Zachodnią (głównie Niemcami, Austrią i północnymi Włochami) i kolejnym polem do rozwijania szarej strefy był nielegalny obrót walutą i importowanymi towarami. Między innymi dzięki takiej działalności poziom życia w Słowenii już w latach 80. XX w. był dużo wyższy niż np. w Portugalii, Hiszpanii, Grecji czy Irlandii ${ }^{9}$.

Biorąc pod uwagę klasyfikację szarej strefy, jaką zaproponowali M.H. Fleming, J. Roman i G. Farrell, należy wyróżnić w niej cztery podstawowe kategorie:

- kryminalną działalność,

- nielegalną,

- działania w obszarze gospodarstw domowych,

- nieformalną.

Pierwsza kategoria obejmuje produkcję dóbr i usług zabronionych przez prawo, w tym zwłaszcza wytwarzanie oraz handel narkotykami. Druga kategoria dotyczy legalnie wytworzonych dóbr i usług, ale są czynione próby polegające na unikaniu w tym zakresie podatków lub też nieewidencjonowania pełnego obrotu. Działania w obszarze gospodarstw domowych skupiają się na aktywności gospodarczej, która jest realizowana na nieznaczną skalę, sporadycznie i odbywa się w ramach wąskiej społeczności. Kategoria nieformalna to działalność niezgłoszona, o różnej skali. Niekiedy dotyczy mikroprzedsiębiorstw, ale może się także odnosić do relatywnie dużych organizacji ${ }^{10}$.

Zbliżony pogląd wyraża L.E. Feige, który także wydziela w szarej strefie cztery grupy, dzieląc ją w zależności od rodzaju łamanych reguł na:

- illegal economy - działania sprzeczne z prawem,

- unreported economy - działania przynoszące dochód jedynie właścicielom,

- undeclared economy - działalność gospodarczą niezgłoszoną instytucjom statystycznym,

- informel economy - działania, w których unika się kosztów wynikających z wszelkich regulacji ${ }^{11}$.

\footnotetext{
9 J. Potocnik, M. Senjur, F. Stiblar, Approaching Europe - Growth. Competitiveness and Integration, Institute of Macroeconomic Analysis and Development, Ljubljana 1996.

10 M.H. Fleming, J. Roman, G. Farrell, The Shadow Economy, „Journal of International Affairs” Vol. 53, Issue 2, 2000.

${ }^{11}$ L.E. Feige, Defining and Estimating Underground and Informal Economies: the New Institutional Economics Approach, Madison University of Wisconsin, Madison 1990.
} 
Komisja Europejska częściej posługuje się terminem gospodarka niezgłoszona (undeclared economy) niż szara strefa (shadow economy). Pod tym pojęciem przyjmie każdą działalność niezgodną z prawem, niezgłoszoną, ale także wykorzystującą luki prawne pomiędzy członkami Wspólnoty Europejskiej ${ }^{12}$. P. Smith natomiast za szarą strefę uważa taką działalność (zarówno legalną, jak i nielegalną), która nie zostaje ujęta w oficjalnych statystykach ${ }^{13}$.

\section{Wyniki badań empirycznych}

Zgodnie z przyjętą metodyką badań w tabeli 1 ujęto rozmiar szarej strefy i poziom redystrybucji w wybranych krajach w latach 1995-2014. Na tej podstawie ustalono związek korelacyjny pomiędzy powyższymi zjawiskami ekonomicznymi.

Współczynnik korelacyjny Pearsona dla Polski wyniósł 0,861, dla Słowacji - 0,895, Czech - 0,717, Węgier - 0,869, Bułgarii - 0,504. Na tej podstawie można przyjąć, że pomiędzy poziomem szarej strefy a wielkością redystrybucji PKB (w przypadku Polski, Słowacji, Czech oraz Węgier) istnieje korelacja bardzo wysoka, a w przypadku Bułgarii jest to korelacja wysoka. Tym samym potwierdzono przyjętą hipotezę badawczą.

Poziom szarej strefy w analizowanych krajach uległ wyraźnemu obniżeniu, chociaż dynamika zmian w poszczególnych krajach była odmienna. W Polsce w $1995 \mathrm{r}$. poziom szarej strefy w relacji do PKB wynosił 33\%, a w 2014 r. już tylko $24 \%$. Warto zwrócić uwagę, że cały czas był to systematyczny spadek. Podobne zmiany odnotowano na Słowacji. Poziom szarej strefy był znacznie niższy niż w Polsce. W 1995 r. było to $22 \%$ PKB, a w 2014 r. - 15\%. Nieznacznie większy rozmiar szarej strefy w porównaniu ze Słowacją notowały Czechy. W 1995 r. było to 23\% PKB, a w 2014 r. - 16\%. Na Węgrzech w 1995 r. był to poziom 27\% PKB, a w 2014 r. - 22\%. W Bułgarii także odnotowano obniżenie rozmiaru szarej strefy. Jednak jej poziom był najwyższy spośród analizowanych państw: w 1995 r. było to 40\% PKB, a w 2014 r. - 31\%. Wyraźne obniżenie poziomu szarej strefy w tej grupie krajów należy wiązać z kilkoma istotnymi czynnikami:

12 European Commission, Undeclared work in an enlarged Union: An analysis of undeclared work, Employment\&European Social Fund, Brussels 2004.

${ }^{13}$ P. Smith, Assessing the Size of the Underground Economy: The Canadian Statistical Perspectives, „Canadian Economic Observer" Nr 3, 1994. 
Tabela 1. Poziom szarej strefy i redystrybucji w wybranych krajach w latach 1995-2014 (\% PKB w wyrażeniu nominalnym)

\begin{tabular}{|c|c|c|c|c|c|c|c|c|c|c|c|c|c|c|c|c|c|c|c|c|c|}
\hline \multirow{3}{*}{ Polska } & lata & ‘95 & ‘96 & ‘97 & '98 & '99 & ‘00 & '01 & ‘02 & '03 & '04 & ‘05 & ‘06 & ‘07 & ‘08 & '09 & ‘10 & $' 11$ & '12 & '13 & '14 \\
\hline & szara strefa & 33,0 & 31,0 & 29,0 & 28,1 & 28,0 & 27,9 & 27,8 & 27,1 & 27,4 & 27,7 & 27,1 & 26,8 & 26,0 & 25,9 & 25,4 & 25,1 & 25,0 & 24,9 & 25,1 & 24,0 \\
\hline & redystrybucja & 51,0 & 50,0 & 48,0 & 49,0 & 46,0 & 45,0 & 45,8 & 44,3 & 44,7 & 42,6 & 43,4 & 43,9 & 42,2 & 43,2 & 44,6 & 45,4 & 43,4 & 42,2 & 41,9 & 41,0 \\
\hline \multirow{2}{*}{\multicolumn{2}{|c|}{ Stowacja }} & 22,0 & 21,0 & 20,9 & 20,8 & 20,7 & 20,0 & 19,1 & 18,4 & 18,2 & 17,1 & 16,8 & 16,7 & 16,4 & 15,5 & 16,2 & 15,8 & 15,6 & 15,2 & 15,1 & 15,0 \\
\hline & & 48,0 & 47,0 & 46,9 & 46,3 & 46,2 & 45,8 & 45,6 & 45,0 & 40,1 & 37,7 & 38 & 36,5 & 34,2 & 34,9 & 41,0 & 39,8 & 38,9 & 38,2 & 38,7 & 37,0 \\
\hline \multirow{2}{*}{\multicolumn{2}{|c|}{ Czechy }} & 23,0 & 22,0 & 21,0 & 20,8 & 20,7 & 20,0 & 19,8 & 19,2 & 19,0 & 18,8 & 18,7 & 18,6 & 18,0 & 18,1 & 17,0 & 16,9 & 16,8 & 16,7 & 16,4 & 16,0 \\
\hline & & 49,0 & 48,0 & 47,2 & 47,1 & 47,0 & 46,7 & 46,0 & 45,6 & 50,0 & 43,3 & 43,0 & 42,0 & 41,0 & 41,1 & 44,7 & 43,7 & 43,2 & 44,5 & 42,3 & 43,0 \\
\hline \multirow{2}{*}{\multicolumn{2}{|c|}{ Węgry }} & 27,0 & 28,0 & 27,7 & 27,6 & 26,7 & 26,6 & 26,1 & 26,0 & 25,6 & 24,8 & 24,7 & 24,9 & 24,2 & 24,1 & 25,5 & 24,0 & 24,1 & 23,9 & 23,0 & 22,0 \\
\hline & & 52,0 & 53,0 & 52,7 & 52,6 & 51,8 & 51,7 & 51,6 & 51,5 & 49,7 & 49,1 & 50,0 & 52,0 & 50,7 & 49,2 & 51,4 & 50,1 & 50,2 & 48,7 & 49,1 & 49,0 \\
\hline \multirow{2}{*}{\multicolumn{2}{|c|}{ Bułgaria }} & 40,0 & 39,0 & 38,8 & 38,7 & 38,6 & 38,5 & 38,4 & 38,2 & 38,0 & 37,8 & 37,7 & 37,6 & 37,8 & 37,0 & 37,9 & 35,0 & 34,0 & 35,5 & 33,0 & 31,0 \\
\hline & & 44,0 & 42,0 & 41,0 & 40,5 & 40,4 & 40,0 & 39,9 & 39,6 & 39,1 & 38,6 & 37,3 & 34,4 & 39,0 & 38,4 & 41.4 & 37,4 & 35,6 & 35,8 & 38,7 & 39,0 \\
\hline
\end{tabular}

Źródło: Obliczenia własne na podstawie: Commission Staff Working Document, Impact Assessment, Brussels, SWD 2012 final, Eurostat, OECD Statistics; F. Schneider, A. Buehn, C.E. Montenegro, New Estimates for the Shadow Economies all over the World, „International Economic Journal” 24(4), 2012; F. Schneider, D. Enste, Shadow Economies Around the World - Size, Causes, and Consequences, „Journal of EconomicLiterature” 38(1), 2000. 
- skutecznością walki z szarą strefą;

- koniecznością likwidacji szarej strefy w związku z przystąpieniem do Unii Europejskiej (m.in. dzięki unifikacji prawa, większej transparentność procesów gospodarczych, zniesieniu ograniczeń w działalności biznesowej, pomocy prawnej od krajów odnoszących sukcesy w walce z szarą strefą);

- świadomością niekorzystnych efektów szarej strefy;

- przeprowadzanymi reformami (wdrożenie zasad gospodarki rynkowej, gdzie wiele źródeł powstawania szarej strefy zostało zlikwidowanych, np. podjęcie legalnej działalności rynkowej w celu wypełnienia określonych nisz);

- spadkiem akceptacji społeczeństwa do działań w szarej strefie; akceptacja była dużo wyższa w tzw. gospodarce niedoboru (planowej przed 1989 r.).

Na podstawie uzyskanych wyników empirycznych można sformułować szereg ważnych konstatacji. Pomimo relatywnie długiego okresu wdrażania rozwiązań gospodarki rynkowej w krajach Europy Środkowej poziom szarej strefy jest nadal dość wysoki. Wynika to z tego, że działalność w niej ulega stałej modyfikacji. Pomimo skuteczności działania organów państwowych nie udaje się szarej strefy w sposób zasadniczy ograniczyć. Animatorzy szarej strefy wykorzystują nie tylko luki w prawie (co powoduje utrudnienia $w$ walce $z$ szarą strefą), ale także wprowadzają nowoczesne metody działania, trudne do wykrycia ${ }^{14}$. Wysoki poziom dystrybucji, a jednocześnie wysoki poziom szarej strefy wynika także z niekorzystnych zjawisk, które pojawiają się w gospodarce rynkowej. Duże bezrobocie skłania ludzi do poszukiwania różnych form zatrudnienia, w tym także pracy nierejestrowanej (bez umów lub też w oparciu o fikcyjne umowy - zaniżone wynagrodzenie). W ten sposób rośnie skala szarej strefy, a jednocześnie zwiększają się wydatki publiczne. Część grup społecznych otrzymuje oficjalne niskie świadczenia i w związku z tym poszukują różnych form pracy, w tym także pracy nielegalnej. Starsze społeczeństwo oznacza większą redystrybucję (chociaż w dużym stopniu zależy to od rozwiązań w systemach emerytalno-rentowych, które nie obciążają budżetu). Natomiast osoby młode (dzięki swojej pracy nierejestrowanej) zasilają szarą strefę. Ważną przesłanką powstania szarej strefy była i nadal pozostaje korupcja. Generalnie wyodrębnia się dwa rodzaje korupcji. Pierwszy rodzaj to korupcja hierarchiczna, drugi - tzw. demokratyczna. Korupcja hierarchiczna polega na opłacaniu się (zazwyczaj w formie łapówek) szeroko rozumianej władzy w celu otrzymania stosownego wsparcia. Innymi słowy, są to transakcje pomiędzy osobami niepodlegającymi relacjom służbowym. Drugi rodzaj to nielegalne przekazywanie pieniędzy dla osób niebędących w szeroko

14 A. Buszko, op.cit. 
rozumianych relacjach podporządkowania ${ }^{15}$. Korupcja sprzyja powstawaniu szarej strefy. Zwłaszcza korupcja hierarchiczna, ale także demokratyczna powoduje zwiększone wydatki publiczne. Te ostatnie mogą być związane $\mathrm{z}$ większym zaangażowaniem państwa np. w przetargach. Przeznaczane na nie kwoty są zawyżane, co znajduje swoje odbicie w wyższym poziomie redystrybucji.

\section{Wybrane następstwa szarej strefy w kontekście redystrybucji}

W zależności od rodzaju szarej strefy jej efekty w odniesieniu do sytuacji makroekonomicznej, a w konsekwencji redystrybucji są różnorodne. Powszechnym zjawiskiem w szarej strefie jest działalność niezgłoszona odpowiednim instytucjom oraz działalność przynosząca korzyść jedynie właścicielom (tzw. unreported i undeclared economy). Taka działalność ma odzwierciedlenie w wielkości PKB. Pomimo osiąganego dochodu (zarówno wśród gospodarstw domowych, jak i przedsiębiorstw) nie jest on ujęty w PKB. Na tej podstawie można przyjąć, że rzeczywisty poziom PKB jest wyższy aniżeli ujęty w odpowiednich danych statystycznych. Poziom redystrybucji dotyczy dochodów, których wysokość oparta jest na zebranych danych. Jest on zatem mniejszy niż faktyczny poziom redystrybucji, jaki mógłby zostać dokonany w oparciu o rzeczywisty PKB. Osoby zatrudnione w szarej strefie (bez odpowiednich umów) otrzymują wynagrodzenie. Wynagrodzenie przyczynia się do zwiększonej konsumpcji, a jednocześnie te same osoby otrzymują (w zależności od rozwiązań prawnych w danym kraju) stosowne świadczenia. Modyfikują tym samym poziom redystrybucji, przyczyniając się jednocześnie do zwiększenia rzeczywistego PKB i przychodów budżetowych z uwagi na podatek VAT (ewentualnie akcyzę). Osoby zatrudnione w szarej strefie dokonują operacji finansowych w legalnym obrocie, a każda taka operacja jest objęta podatkiem VAT lub akcyzą. Jednocześnie maleją przychody budżetowe z tytułu podatków dochodowych (PIT, CIT) oraz zasadniczo zmniejszają się obciążenia z tytułu kosztów pracy. W dłuższej perspektywie osoby nie są w stanie zgromadzić odpowiednich kwot i uzyskać wyższych świadczeń emerytalnych bądź rentowych. Tego typu grupy stają się podmiotem pomocy społecznej,

15 M.R. Kumara Swamy, Financial Management Analysis of Money Laundering, Corruption and Unethical Business Practices: Case Studies of India, Nigeria and Russia, "Journal of Financial Management and Analysis" 24 (I), 2011. 
a w ślad za tym zwiększa się poziom wydatków publicznych - z uwagi na konieczność zapewnienia przynajmniej bezpieczeństwa socjalnego.

W związku z powyższym ważną kwestią pozostaje szacowanie wielkości szarej strefy w kontekście PKB i ewentualnych strat dochodów budżetowych. Ten problem badawczy podjęto w Turcji. Na podstawie badań empirycznych zrealizowanych przez Ahmeta Burçina Yereli, Ibrahima Erdema Seçilmis oraz Alparslana Basaran stwierdzono, że szara strefa przyczynia się nie tylko do zmniejszenia dochodów budżetowych, ale również sprzyja pogłębieniu się zjawisk kryzysowych. W analizowanym okresie, przy relatywnie wysokim poziomie szarej strefy (około 22\% PKB w latach 1991-2003) w Turcji występował problem nierównowagi budżetowej i braku możliwości redukcji zadłużenia ${ }^{16}$.

\section{Podsumowanie}

Na podstawie przeprowadzonych badań potwierdzono przyjętą hipotezę. Poziom wydatków publicznych jest silnie stochastycznie dodatnio skorelowany z poziomem szarej strefy, czyli występuje związek pomiędzy redystrybucją a szarą strefą. Osiągnięto także założone cele. Przedstawiono zachodzące w szarej strefie procesy, które implikują poziom redystrybucji. Wiele problemów wynikających z ogólnej sytuacji makroekonomicznej skutkuje z jednej strony powstaniem szarej strefy, a z drugiej rzutuje na poziom wydatków publicznych. W kontekście przeprowadzonego wywodu należy stwierdzić, że szara strefa powoduje negatywne efekty gospodarcze, a jej likwidacja jest niezmiernie trudna. W niektórych krajach (np. Słowenia) występuje dość powszechna akceptacja dla swoistej powstałej tam szarej strefy. Bardzo niebezpieczna jest kategoria szarej strefy związanej z działalnością kryminalną. Taka działalność jest typową szarą strefą, ale jeszcze powoduje przesunięcie działań z legalnej sfery gospodarki do nielegalnej. Z uwagi na obecność przestępczości zorganizowanej przedsiębiorcy starają się tak funkcjonować, aby pozostać niezauważonymi dla organów kontroli skarbowej oraz przedstawicieli grup kryminalnych.

Osoby kreujące szarą strefę zmieniają formę i skalę działania. $\mathrm{Z}$ tego względu trudno jest oszacować wielkość szarej strefy, jej efekty. W miejsce zlikwidowanej działalności pojawia się nowa - odpowiednio zmieniona, skuteczniejsza. Tym niemniej

16 A.B. Yereli, Ý.E. Seçilmiţ, A. Baţaran, Shadow Economy and Public Debt Sustainability in Turkey, „Economic Annals" Nr 173, 2007. 
problem szarej strefy, jej uwarunkowań, efektów, jakie powoduje, powinien być przedmiotem dalszych badań i analiz.

\section{Literatura}

Balcerowicz L., Ekonomia i etyka państwa socjalnego, Wykład dla Polskiej Rady Biznesu, Warszawa, 1.02.2006.

Barczyk R., Lubiński M., Dylematy stabilizowania koniunktury, Wydawnictwo UE w Poznaniu, Poznań 2009.

Buszko A., Finanse przestępczości zorganizowanej, TNOiK, Toruń 2014.

Buszko A., Długosz J., Skorwider-Namiotko J., Szumowska K., Zarzadzanie przedsiębiorstwem szarej strefy, Difin, Warszawa 2015.

Commission Staff Working Document, Impact Assessment, Brussels, SWD 2012 final.

Eilat Y., Zinnes C., The Shadow Economy in Transition Countries: Friend or Foe? A Policy Perspective, „World Development” Vol. 30, Nr 7, 2002.

European Commission, Undeclared work in an enlarged Union: An analysis of undeclaredwork, Employment\&European Social Fund, Brussels 2004.

Eurostat.

Feige L.E., Defining and Estimating Underground and Informal Economies: the New Institutional Economics Approach, Madison University of Wisconsin, Madison 1990.

Fleming M.H., Roman J., Farrell G., The Shadow Economy, „Journal of International Affairs" Vol. 53, Issue 2, 2000.

Johnson S., Kaufniann D., Zoido-Lobaton P., Regulatory Discretion and the Unofficial Economy, „Economic Review” 88(2), 1998.

Kumara Swamy M.R., Financial Management Analysis of Money Laundering, Corruption and Unethical Business Practices: Case Studies of India, Nigeria and Russia, „Journal of Financial Management and Analysis" 24 (I), 2011.

Małecka-Ziembińska E., Finanse publiczne państw OECD $w$ dobie kryzysu, „Zeszyty Naukowe PTE” nr 10, 2011.

Mróz B., The shadow economy in Poland. Causes, Manifestations, Economic and Social Effects, „Journal of Management and Financial Sciences” Vol. III, Issue 3, April 2010.

Pasternak-Malicka M., Model Laffera jako wdrożenie mainstreamowego pogladu na zależność pomiędzy wysokościa podatku a ekspansją szarej strefy, w: Rozwój nauki o finansach. Stan obecny i pożądane kierunki jej ewolucji, red. nauk. J. Ostaszewski, E. Kosycarz, S. „Przedsiębiorczość” Oficyna Wydawnicza SGH, Warszawa 2014.

Potocnik J., Senjur M., Stiblar F., Approaching Europe - Growth. Competitiveness and Integration, Institute of Macroeconomic Analysis and Development, Ljubljana1996. 
Schneider F., Buehn A., Montenegro C.E., New Estimates for the Shadow Economies all over the World, „International Economic Journal” 24(4), 2012.

Schneider F., Enste D., Shadow Economies Around the World - Size, Causes, and Consequences, „Journal of Economic Literature” 38(1), 2000.

Smith P., Assessing the Size of the Underground Economy: The Canadian Statistical Perspectives, „Canadian Economic Observer” Nr 3, 1994.

Thomas J.J., Quantifying the Black Economy Measurement without Theory' Yet Again, „The Economic Journal” 109/456, 1999.

Yereli A.B., Seçilmiţ Ý.E., Baţaran A., Shadow Economy and Public Debt Sustainability in Turkey, „Economic Annals” Nr 173, 2007.

\section{The shadow zone and redistribution of GDP: implications and conditions}

The main objective of this paper is to establish the relationship between the size of the shadow economy and the level of redistribution of GDP. Pearson correlation coefficient was used for small samples. The hypothesis that the level of public expenditure is strongly stochastically positively correlated with the level of the shadow economy has been confidently verified. The study included Poland, Hungary, the Czech Republic, Slovakia and Bulgaria between 1995-20014. The article describes the categories of the shadow economy and the conditions of its creation in the context of the macroeconomic effects of redistribution of GDP.

Keywords: grey economy, redistribution, budget, change, dynamics

\section{Zone d'ombre et redistribution du PIB: implications et conditions}

L'objectif principal de cet article est d'établir la relation entre la taille de l'économie souterraine et le niveau de redistribution du PIB. Le coefficient de corrélation de Pearson a été utilisé pour les petits échantillons. L’hypothèse selon laquelle le niveau des dépenses publiques est fortement, stochastiquement et positivement corrélé avec le niveau de l'économie souterraine a été vérifiée d'une manière précise et pertinente. L'étude a inclus la Pologne, la Hongrie, la République tchèque, la Slovaquie et la Bulgarie entre 1995 et 2014. Larticle décrit les catégories d'économie souterraine et les conditions de son développement dans le contexte des effets macroéconomiques de la redistribution du PIB. 
Mots-clés: économie souterraine/zone grise, redistribution, budget, changement, dynamique

\section{Теневая экономика и перераспределение ВВП: последствия и условия}

Статья имеет две цели: основную и вторичную. Основная цель состоит в установлении связи между размером теневой экономики и уровнем перераспределения ВВП. В работе используется коэффициент корреляции Пирсона для малых выборок. Подтверждается выдвинутая гипотеза, что уровень государственных расходов сильно стохастически положительно коррелирует с уровнем теневой экономики. Исследование проводилось на примере Польши, Венгрии, Чехии, Словакии и Болгарии за период 1995-2014 гг. Описывается категория неформальной экономики, условия ее создания и ее макроэкономические последствия в контексте перераспределения ВВП.

Ключевые слова: теневая экономика, перераспределение, бюджет, изменения, динамика 